\title{
Assessment of Continuous Oil and Gas Resources in the Mowry Shale, Wind River Basin Province, Wyoming, 2020
}

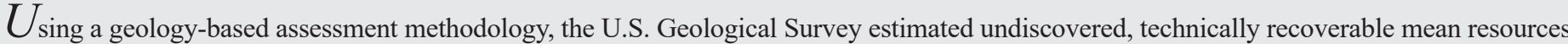
of 288 million barrels of oil and 2.6 trillion cubic feet of gas in the Mowry Shale in the Wind River Basin Province, Wyoming.

\section{Introduction}

The U.S. Geological Survey (USGS) quantitatively assessed the potential for undiscovered, technically recoverable, continuous (unconventional) oil and gas resources in the Cretaceous Mowry Shale in the Wind River Basin Province, Wyoming (fig. 1). In the Wind River Basin, the Mowry consists of two distinct units: (1) a lower soft clay-rich shale and (2) an upper siliceous part composed of dark gray to brown organic-rich mudrock with numerous siltstone, very fine sandstone, and bentonite beds (Keefer and Johnson, 1997; Kirschbaum and others, 2019). The strata were deposited in the northern arm of the Western Interior Seaway, an epicontinental seaway that, at various times, occupied an elongate, northsouth foreland basin that developed east of the tectonically active Cordilleran orogenic belt of western North America (Kauffman and Caldwell, 1993; Roberts and Kirschbaum, 1995; DeCelles, 2004). From the Late Cretaceous through early Eocene, the Laramide orogeny fragmented the central part of the foreland basin into numerous smaller basins, including the Wind River Basin, that were flanked by rising basement-cored uplifts. These basins subsided rapidly and were depocenters for the accumulation of thick continental and lacustrine sediments from the latest Cretaceous through middle Miocene (Love, 1988).

\section{Total Petroleum System and Assessment Units}

Johnson and others (2007) defined the Cretaceous-Lower Tertiary Composite Total Petroleum System (TPS) in the Wind River Basin Province to include strata from the base of the Lower Cretaceous to the base of the Paleocene Waltman Shale Member of the Fort Union Formation and to include lower Eocene strata where the Waltman is absent. The Mowry Shale is an element of the Cretaceous-Lower Tertiary Composite TPS and includes both source and reservoir rocks. The source and reservoir rocks occur in the upper siliceous part of the Mowry and have total organic carbon contents of as much as 5 weight percent (Finn, 2007; Birdwell and others, 2019; Kirschbaum and others, 2019). The organic matter consists of Type II kerogen with some mixed Type II/III, with hydrogen index values of as much as 531 milligrams of hydrocarbon per gram of organic carbon. Potential reservoirs in the upper siliceous part of the Mowry have silica contents of as much as 90 percent (Birdwell and others, 2019). The upper siliceous part of the Mowry Shale is more organicrich and oil-prone in the central and eastern parts of the basin (Finn, 2007). Thermal maturity mapping, based on vitrinite reflectance $\left(\mathrm{R}_{\mathrm{o}}\right)$, shows that the Mowry is thermally mature for oil generation
(0.6-1.35 percent $\mathrm{R}_{\mathrm{o}}$ ) along the western and southern margins of the basin and mature for gas generation (greater than 1.35 percent $\mathrm{R}_{\mathrm{o}}$ ) in the deeper central and northern parts of the basin (Finn and Pawlewicz, 2013). These organic-rich shales matured during the Late Cretaceous through early Eocene Laramide orogeny and postLaramide burial (Roberts and others, 2007).

The geologic model for Mowry Shale continuous accumulations is that oil and gas were generated from oil-prone source rocks primarily during Laramide and post-Laramide burial. Oil and gas were partially retained within the Mowry following generation and migration into adjacent reservoirs. Two continuous assessment units (AUs) were defined: (1) the Wind River Mowry Shale Oil AU encompasses the area within the oil generation window (0.60-1.35 percent $\mathrm{R}_{\mathrm{o}}$ ), and (2) the Wind River Mowry Shale Gas AU includes the area where oil has been cracked to gas (greater than 1.35 percent $\mathrm{R}_{\mathrm{o}}$ ).

Assessment input data are summarized in table 1. Input data for estimated ultimate recoveries of wells are taken from the geologic analog in the Powder River Basin Province and from other U.S analogs.

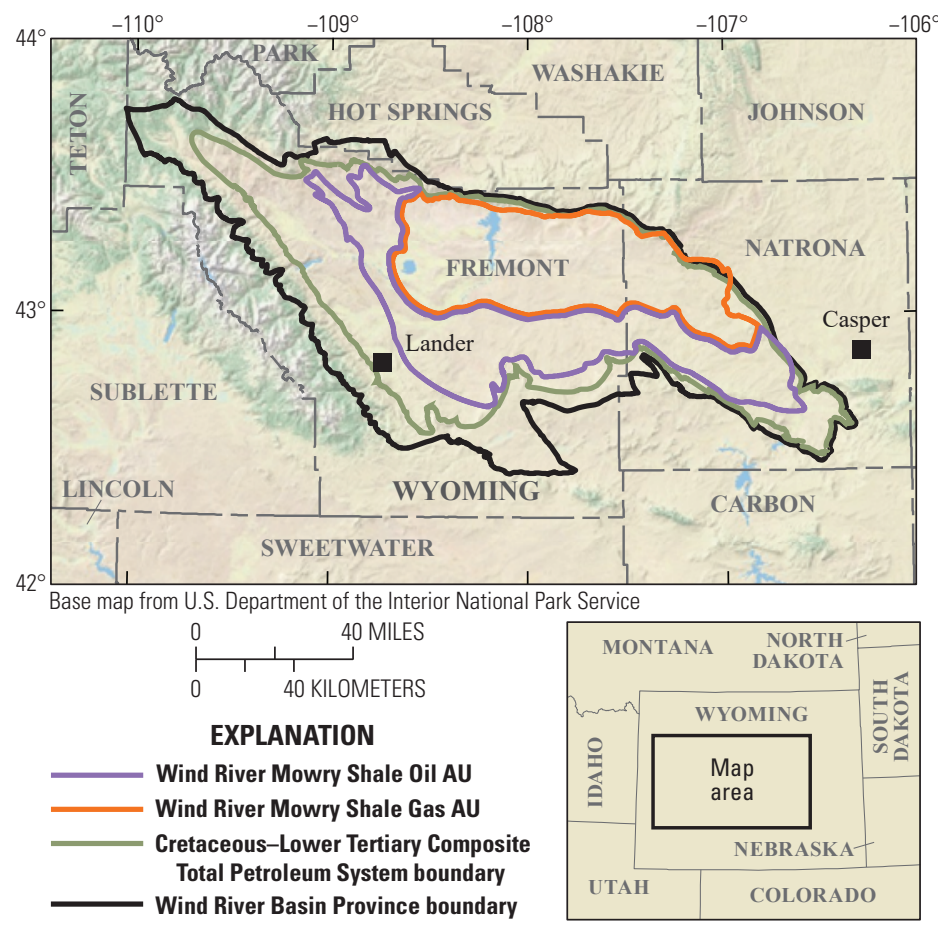

Figure 1. Map showing the continuous oil and gas assessment units (AUs) in the Mowry Shale in the Wind River Basin Province, Wyoming. Province boundary is from Johnson and others (2007). 
Table 1. Key input data for two shale assessment units in the Mowry Shale, Wind River Basin Province, Wyoming.

[Well drainage area, success ratio, and estimated ultimate recovery are defined using U.S. shale-oil and shale-gas analogs. The average EUR input is the minimum, median, maximum, and calculated mean. Gray shading indicates not applicable. AU, assessment unit; \%, percent; EUR, estimated ultimate recovery (per well); MMBO, million barrels of oil; BCFG, billion cubic feet of gas]

\begin{tabular}{|c|c|c|c|c|c|c|c|c|}
\hline \multirow{2}{*}{$\begin{array}{l}\text { Assessment input data- } \\
\text { Continuous AUs }\end{array}$} & \multicolumn{4}{|c|}{ Wind River Mowry Shale Oil AU } & \multicolumn{4}{|c|}{ Wind River Mowry Shale Gas AU } \\
\hline & Minimum & Mode & Maximum & $\begin{array}{c}\text { Calculated } \\
\text { mean }\end{array}$ & Minimum & Mode & Maximum & $\begin{array}{c}\text { Calculated } \\
\text { mean }\end{array}$ \\
\hline Potential production area of AU (acres) & 1,000 & 540,400 & $1,233,400$ & 591,600 & 1,000 & 648,000 & $1,319,500$ & 656,167 \\
\hline Average drainage area of wells (acres) & 60 & 100 & 160 & 106.7 & 80 & 120 & 160 & 120 \\
\hline Success ratio $(\%)$ & 10 & 50 & 90 & 50 & 10 & 50 & 90 & 50 \\
\hline Average EUR (MMBO, oil; BCFG, gas) & 0.04 & 0.1 & 0.15 & 0.101 & 0.2 & 0.8 & 2 & 0.856 \\
\hline AU probability & 1.0 & & & & 1.0 & & & \\
\hline
\end{tabular}

\section{Undiscovered Resources Summary}

The USGS quantitatively assessed continuous oil and gas resources in two delineated AUs (table 2) in the Mowry Shale in the Wind River Basin Province, Wyoming. For undiscovered, technically recoverable continuous oil and gas resources, the estimated mean totals are 288 million barrels of oil (MMBO) with an F95-F5 fractile range from 67 to 609 MMBO; 2,613 billion cubic feet of gas (BCFG), or 2.6 trillion cubic feet of gas, with an F95-F5 fractile range from 575 to 5,799 BCFG; and 11 million barrels of natural gas liquids (MMBNGL) with an F95-F5 fractile range from 2 to $23 \mathrm{MMBNGL}$.

\section{Table 2. Results for two continuous assessment units in the Mowry Shale, Wind River Basin Province, Wyoming.}

[Results shown are fully risked estimates. F95 represents a 95-percent chance of at least the amount tabulated; other fractiles are defined similarly. Gray shading indicates not applicable. MMBO, million barrels of oil; BCFG, billion cubic feet of gas; NGL, natural gas liquids; MMBNGL, million barrels of natural gas liquids]

\begin{tabular}{|c|c|c|c|c|c|c|c|c|c|c|c|c|c|c|}
\hline \multirow{3}{*}{$\begin{array}{l}\text { Total petroleum system and } \\
\text { assessment units (AUs) }\end{array}$} & \multirow{3}{*}{$\begin{array}{c}\text { AU } \\
\text { proba- } \\
\text { bility }\end{array}$} & \multirow{3}{*}{$\begin{array}{c}\text { Accumu- } \\
\text { lation } \\
\text { type }\end{array}$} & \multicolumn{12}{|c|}{ Total undiscovered resources } \\
\hline & & & \multicolumn{4}{|c|}{ Oil (MMBO) } & \multicolumn{4}{|c|}{ Gas (BCFG) } & \multicolumn{4}{|c|}{ NGL (MMBNGL) } \\
\hline & & & F95 & F50 & F5 & Mean & F95 & F50 & F5 & Mean & F95 & F50 & F5 & Mean \\
\hline \multicolumn{15}{|c|}{ Cretaceous-Lower Tertiary Composite Total Petroleum System } \\
\hline Wind River Mowry Shale Oil AU & 1.0 & \begin{tabular}{|l|} 
Oil \\
\end{tabular} & 67 & 258 & 609 & 288 & 67 & 258 & 610 & 288 & 2 & 8 & 18 & 9 \\
\hline Wind River Mowry Shale Gas AU & 1.0 & Gas & & & & & 508 & 2,016 & 5,189 & 2,325 & 0 & 1 & 5 & 2 \\
\hline Total undiscovered continuous resources & & & 67 & 258 & 609 & 288 & 575 & 2,274 & 5,799 & 2,613 & 2 & 9 & 23 & 11 \\
\hline
\end{tabular}

\section{References Cited}

Birdwell, J.E., Finn, T.M., French, K.L., Schenk, C.J., Kirschbaum, M.A., and Lillis, P.G., 2019, Mineralogical and geochemical properties of the Cretaceous Mowry Shale in the Wind River Basin, Wyoming near the Casper Arch [abs.], in 2019 American Association of Petroleum Geologists Rocky Mountain Section Meeting, Cheyenne, Wyo., September 15-18, 2019, Proceedings: American Association of Petroleum Geologists, accessed November 18, 2020, at http://www.searchanddiscovery.com/ abstracts/html/2019/cheyenne-90357/abstracts/2019.RMS.35.html.

DeCelles, P.G., 2004, Late Jurassic to Eocene evolution of the Cordilleran thrust belt and foreland basin system, western U.S.A: American Journal of Science, v. 304, no. 2 , p. $105-168$.

Finn, T.M., 2007, Source rock potential of Upper Cretaceous marine shales in the Wind River Basin, Wyoming, chap. 8 of USGS Wind River Basin Province Assessment Team, comps., Petroleum systems and geologic assessment of oil and gas in the Wind River Basin Province, Wyoming: U.S. Geological Survey Digital Data Series DDS-69-J, 24 p.

Finn, T.M., and Pawlewicz, M.J., 2013, Maps showing thermal maturity of Upper Cretaceous marine shales in the Wind River Basin, Wyoming: U.S. Geological Survey Scientific Investigations Map 3266, 13 p., 1 sheet, scale 1:500,000, accessed February 2, 2019, at https://doi.org/10.3133/sim3266.

Johnson, R.C., Finn, T.M., Kirschbaum, M.A., Roberts, S.B., Roberts, L.N.R., Cook, T., and Taylor, D.J., 2007, The Cretaceous-Lower Tertiary Composite Total Petroleum System, Wind River Basin, Wyoming, chap. 4 of USGS Wind River Basin Province Assessment Team, comps., Petroleum systems and geologic assessment of oil and gas in the Wind River Basin Province, Wyoming: U.S. Geological Survey Digital Data Series DDS-69-J, 96 p.

\section{For More Information}

Assessment results are also available at the USGS Energy Resources Program website at https://energy.usgs.gov.
Kauffman, E.G., and Caldwell, W.G.E., 1993, The Western Interior Basin in space and time, in Caldwell, W.G.E., and Kauffman, E.G., eds., Evolution of the Western Interior Basin: Geological Association of Canada, Special Paper 39, p. 1-30.

Keefer, W.R., and Johnson, R.C., 1997, Stratigraphy and correlation of Cretaceous and Paleocene rocks, west-central Wind River Basin, Wyoming: U.S. Geological Survey Oil and Gas Investigations Chart OC-146-B.

Kirschbaum, M.A., Finn, T.M., Schenk, C.J., and Hawkins, S.J., 2019, Lithologic descriptions, geophysical logs, and source-rock geochemistry of the U.S. Geological Survey Alcova Reservoir AR-1-13 core hole, Natrona County, Wyoming: U.S. Geological Survey Scientific Investigations Report 2019-5123, 33 p., accessed November 18, 2020, at https://doi.org/10.3133/sir20195123.

Love, D.J., 1988, Geology of the Wind River Basin, central Wyoming, in Sloss, L.L., ed., Sedimentary cover-North American craton-United States: The Geological Society of America, The geology of North America, v. D-2, p. 196-200.

Roberts, L.N.R., Finn, T.M., Lewan, M.D., and Kirschbaum, M.A., 2007, Burial history, thermal maturity, and oil and gas generation history of petroleum systems in the Wind River Basin Province, central Wyoming, chap. 6 of USGS Wind River Basin Province Assessment Team, comps., Petroleum systems and geologic assessment of oil and gas in the Wind River Basin Province, Wyoming: U.S. Geological Survey Digital Data Series DDS-69-J, 26 p.

Roberts, L.N.R., and Kirschbaum, M.A., 1995, Paleogeography of the Late Cretaceous of the Western Interior of middle North America - Coal distribution and sediment accumulation: U.S. Geological Survey Professional Paper 1561, 115 p.

\section{Mowry Shale Assessment Team}

Thomas M. Finn, Christopher J. Schenk, Tracey J. Mercier, Marilyn E. Tennyson, Cheryl A. Woodall, Kristen R. Marra, Phuong A. Le, Heidi M. Leathers-Miller, and Geoffrey S. Ellis 